\title{
1 Investigating regional patterning in archaeological remains by pairing 2 extensive survey with a lidar dataset: the case of the Manu'a Group, 3 American Samoa
}

4

\author{
Seth Quintus (Corresponding Author) \\ University of Auckland, Department of Anthropology \\ squi546@aucklanduni.ac.nz \\ University of Auckland, Private Bag 92019, Auckland, New Zealand \\ Tel: +64 9 373-7599 \\ Jeffrey T. Clark \\ North Dakota State University, Department of Sociology and Anthropology \\ Stephanie S. Day \\ North Dakota State University, Department of Geosciences \\ Donald P. Schwert \\ North Dakota State University, Department of Geosciences
}

\begin{abstract}
:
\end{abstract}
A long standing research approach in island Oceania is the examination of community and regional level patterning of archaeological remains. However, these efforts are impeded by heavy vegetation and rugged terrain, which limit the implementation and productivity of traditional archaeological methods. Aerial lidar data provide an opportunity to survey large archaeological landscapes effectively and efficiently in these environments. In this paper, we present the results of a lidar-based survey and analysis of community-level spatial patterning for at sites in the Manu'a Group of American Samoa. Using lidar data in conjunction with pedestrian survey results, we first established the suitability of lidar for identifying archaeological features, and then applied the technique to a previously unexamined landscape. We were able to record archaeological remains and analyse the data to discern spatial patterning in their distribution. The patterning of these remains is broadly comparable, though not identical, to that of three other settlement zones on Olosega and the adjacent island of Ofu, which previously were intensively surveyed. The differences in the characteristics and distribution of structural features within and between these four settlement zones may reflect differences in social status and ranking.

Keywords: Lidar, Remote sensing, Settlement Patterns, Social Hierarchy, Polynesia 


\section{INTRODUCTION}

Landscape and settlement pattern studies have diversified and maturedin Polynesia since the pioneering investigations of Roger C. Green in the 1960s (see Green 2002). Settlement pattern studies have been supplemented more recently by advances in geospatial technologies (e.g., Field 2003, 2005; Field et al. 2010; Kurashima and Kirch 2012;Ladefoged et al. 2009, 2013; McCoy et al. 2011a,b; Morrison 2012). Of particular importance has been the application of aerial lidar(Light Detection and Ranging) for understanding landscapes, especially in forested areas (e.g., Opitz and Cowley 2013). Lidardatasets are just beginning to be used on some islands of the eastern Pacific for revealing the distribution of archaeological remains (Ladefoged et al. 2011; McCoy et al. 2011a), but such studies are still uncommon because datasets are available for so few islands. As lidar becomes increasingly available, however, the analyses of resultant datasetswill present opportunities for more-efficient examinations of large-scale settlement patterns.

Settlement pattern studies have made important contributions to archaeological research in the Samoan Archipelago (e.g., Clark and Herdrich 1993; Green and Davidson 1969, 1974; Hunt and Kirch 1988; Jennings and Holmer 1980; Jennings et al. 1976; Pearl 2004; Quintus and Clark 2012). Thesestudies, conducted within local environmental constraints, have resulted in a growing understanding of the nature and distribution of archaeological features across small sections of the landscape. Nevertheless, because of the dense vegetation and often rugged topography, the vast majority of the Samoanislands are still unexamined.Consequently, there remains aneed for enhanced understanding of large regional settlement patterns and the relationships among settlement zones through time.

Using alidar dataset that has recently become publicly available for the Territory of American Samoa, we assess the benefits and limitations of that dataset for the study of archaeological landscapes on the islands of Olosega and Ofu, in the Manu'a Group, which are the eastern-most islands of the Samoan Archipelago. By comparing the locations and configurations of upland archaeological features identified through ground survey with apparent features observed in the lidar dataset, we are able to establish a set of techniques to digitally identify and record features in an area not previously investigated on Olosega. Analyses of data from all of the upland settlement zones described for Ofu and Olosega demonstrate that the lidar dataset can contribute significantly to our understanding of community and regional spatial patterning of archaeological features on these islands.

\section{BACKGROUND}

\subsection{The Islands}

The Samoan Archipelago, located in West Polynesia,comprises nine inhabited islands:

68 Savai'i, Apolima, Manono, 'Upolu, Tutuila, Aunu’u, Ofu, Olosega, and Ta'u. The first four

69 islands are part of the Independent Nation of Samoa, with Savai'i and 'Upolu being the largest of 
the group. The latter five islands are part of the U.S. Territory of American Samoa. Ofu,

71 Olosega, and Ta'u form the Manu'a group, which issomewhat different, environmentally and

72 culturally, from the rest of the archipelago (Mead 1969; Meleiseā 1995). Of these islands, Ta'u is

73 the largest $\left(36 \mathrm{~km}^{2}\right)$, Ofu next $\left(7 \mathrm{~km}^{2}\right)$, and Olosega $\left(5 \mathrm{~km}^{2}\right)$ the smallest. The islands of Manu'a

74 are located proximal to one another: Ofu and Olosega separated by a $\approx 100 \mathrm{~m}$-wide channel, with

$75 \mathrm{Ta} \mathbf{\mathrm { u }} \approx 10 \mathrm{~km}$ to the southeast. Of particular interest to this study are the interior upland zones of

76 Ofu and Olosega (Fig. 1).

The uplands of Ofu range in elevation from $\approx 45-495$ masl. Slope ranges from $\approx 10-45^{\circ}$, increasing with elevation. Streams are few and flow intermittently during times of heavy rain, which are frequent. On the north side of the island the elevation drops from the high ridgeline into a large area of relatively gently sloping ground that is the remnant of a volcanic caldera. The north side of the calderais a cliff that marks the north coast of the island. Vegetation throughout the caldera and its defining slopes is a mix of native and introduced species. At lower elevations, vegetation is largely economic or secondary forests (Liu and Fischer 2007) with equally modified understories. Rain and cloud forests grow at the higher elevations. The upland zone of Olosega ranges in elevation from $\approx 60-640$ masl, and slope ranges from $\approx 10-40^{\circ}$. Streams are intermittent,and several dissected channels are situatednear the center of the island.Like Ofu, the vegetation is dense, in both canopy and understory, and is classified as modified/economic, secondary, or cloud/rain forest, with these zones in a linear progression from lower tohigher elevations.

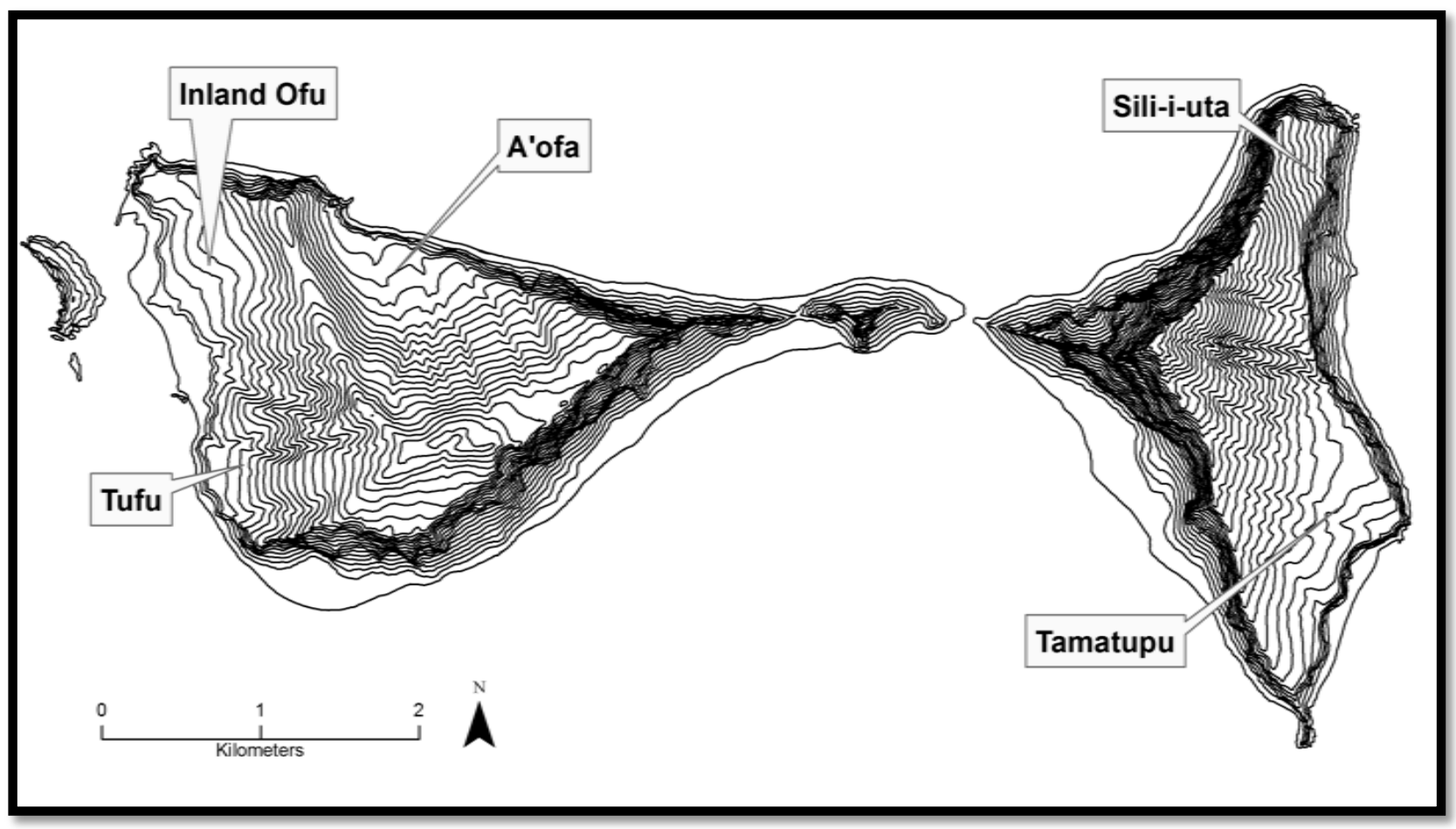




\subsection{Settlement in the Uplands}

Three primaryanthropogenic feature types are the focus of this study: terraces, ditches, and star mounds.Terraces are defined herein as artificially flattened earthen structures with three or less freestanding sides. These featuresserved a variety of functions but most represent residential activities. The presence of water-worn coral and/or basalt gravel scattered over a terrace surface is taken to reflect a house/residential activity floor;the frequent presence of stone artefacts and occasional cooking features reinforces the assessment of a residential function.Larger residential terraces likely served as foundations for multiple structures that constituted individual households.Terraces that we have preliminarilydesignated non-residential lack water-worn coral/basalt,artefacts, and ovens/fireplaces. These are typically smaller than residential terraces and are situated on the steeper slopes peripheral to the residential area.We tentatively propose that the non-residential terraces were related to agricultural production, either as planting terraces or as work/rest stations. Another terrace type is the ditched terrace (Quintus 2011:84-85). These features are more-or-less oval-shaped terraces bounded entirely or nearly so by a shallow ditch. Typically, these terraces have coral paving but the coralsare large, flat slabs rather than water-worn rubble. On the basis of these and other characteristics, Quintus (2011) has argued that ditched terraces were ceremonial/religious structures.

Ditches are defined as artificial channels that are longer than they are wide. The feature class is diverse, but many of these features are interpreted as drainage features given their size and spatial distribution (Quintus 2012, 2014; Quintus and Clark 2012).Ditches in Samoa serving functions other than fortification or sunken path are rare outside the Manu'a Group, but possible drainage ditches were briefly described for inland Falefa Valley of 'Upolu by Davidson (1974a:5) and Ishizuki (1974:49).

Star mounds are a feature type unique to the Samoan Archipelago. These structures are platformsconstructed of stacked rocks or earthen fill with rock facing, having one to 11 projections on the perimeters (see Herdrich 1991). Although their function has been debated, they are often equated with pigeon catching mounds. Pigeon catching was a chiefly sport that functioned more as an avenue for status rivalry than subsistence activity(Herdrich 1991:391; Herdrich and Clark 1993; Krämer 1902, II:388). Because of this, star mounds are often associated with the development of a social hierarchy, ranking, and labor control (Herdrich and Clark 1993; Quintus and Clark 2012). The construction of the features themselves would likely have required group cooperation and coordination. Many of the features are over a meter in height, exhibit stone facing, and can have surface areas of over 1,000 $\mathrm{m}^{2}$.

Prior pedestrian surveys of upland areas of Ofu and Olosega thought to be likely locations for human occupation revealed settlement zones marked by high densities of terraces, with other features, particularly star mounds, scattered beyond those zones. These settlements cannot properly be called villages because contemporary Samoan communities that appear to be a single village may in fact be composed of two or more conceptually and politically distinct 
131 villages. One might use the term site in reference to a settlement zone, but the features are

132 dispersed over fairly large areas that show variability in the density of features present. There are

133 also different strategies as to how archaeologists working in Samoa have applied the concept of site, ranging from an entire settlement zone be regarded as a single site (e.g., Clark and Herdrich 1993; Kirch and Hunt 1993; Quintus and Clark 2012) to single households (house platform/floor and associated features such as ovens and pits) within large settlement zones given designated distinct sites (e.g., Best 1992; Jennings and Holmer 1980). For analytical purposes we will use the term settlement zone in this paper, but for recording and identification purposes we have assigned a single site number to each of the settlement zones.

On Ofu, upland settlement zones with high feature density areas were documented in three locations (Clark et al. 2012; Quintus 2011, 2014). Well known to local residents, but not reported in earlier site inventories, is the settlement zone of A'ofa (site AS-13-39) (Fig. 1), the features of which are distributed throughout the old caldera basin on the north side of the island. A second settlement zone was found in the uplands at Tufu (AS-13-42), overlooking the west coast of the island, just to the south of the modern village of Ofu. A third zone has been preliminarily identified on the slopes above modern Ofu Village, on the northwest side of the island. We tentatively refer to this settlement zone as Inland Ofu, but only limited reconnaissance has taken place in that area, so it will not be discussed further here.Residential terraces are the most common feature at A'ofa and Tufu, with likely non-residential terraces also present on the higher slopes. Ditches interpreted as drainage features are found at both settlement zones, typically surrounding parcels of sloping land that may have served as cultivation plots. Two varieties of these features have been identified, those with a single branch defining a single parcel and those with multiple branches defining a network of parcels.Ditched terraces are rare, perhaps absent, on Ofu, and star mounds are uncommon on the surrounding ridgetops.

The largest zone of settlement is on Olosega and is referred to in oral history as Tamatupu (AS-12-2). While only a subset of the land constituting the probable settlement zone of Tamatupu ( $\approx 60$ of $\approx 120$ ha) has been examined on the ground, it is the most intensively surveyed of all the Manu'a upland sites (Quintus 2011, 2012; Quintus and Clark 2012).The

159 Tamatupu features are distributed over the southern half of the uplands east of the major north-

160 south ridgeline of the island. The entire settlement zone is divided by a single, long ditch that runs perpendicular to the slope, or roughly parallel to the coast.The size of terraces, which functioned as both residential and non-residential features, decrease with increase in elevation. The largest residential terrace is the most centrally located feature in the surveyed areaand is likely the central feature of the entire settlement zone. The ditch separates economic forest (downslope) from secondary forest (upslope), a pattern suggestive of arboriculture in the residential portion of the settlement zone and shifting cultivation upslope (Fig. 2). Star moundsare distributed on the ridgeline overlooking the rest of the settlement zone in the highest density known forthe archipelago (Quintus and Clark 2012). Ditched terraces are dispersed 


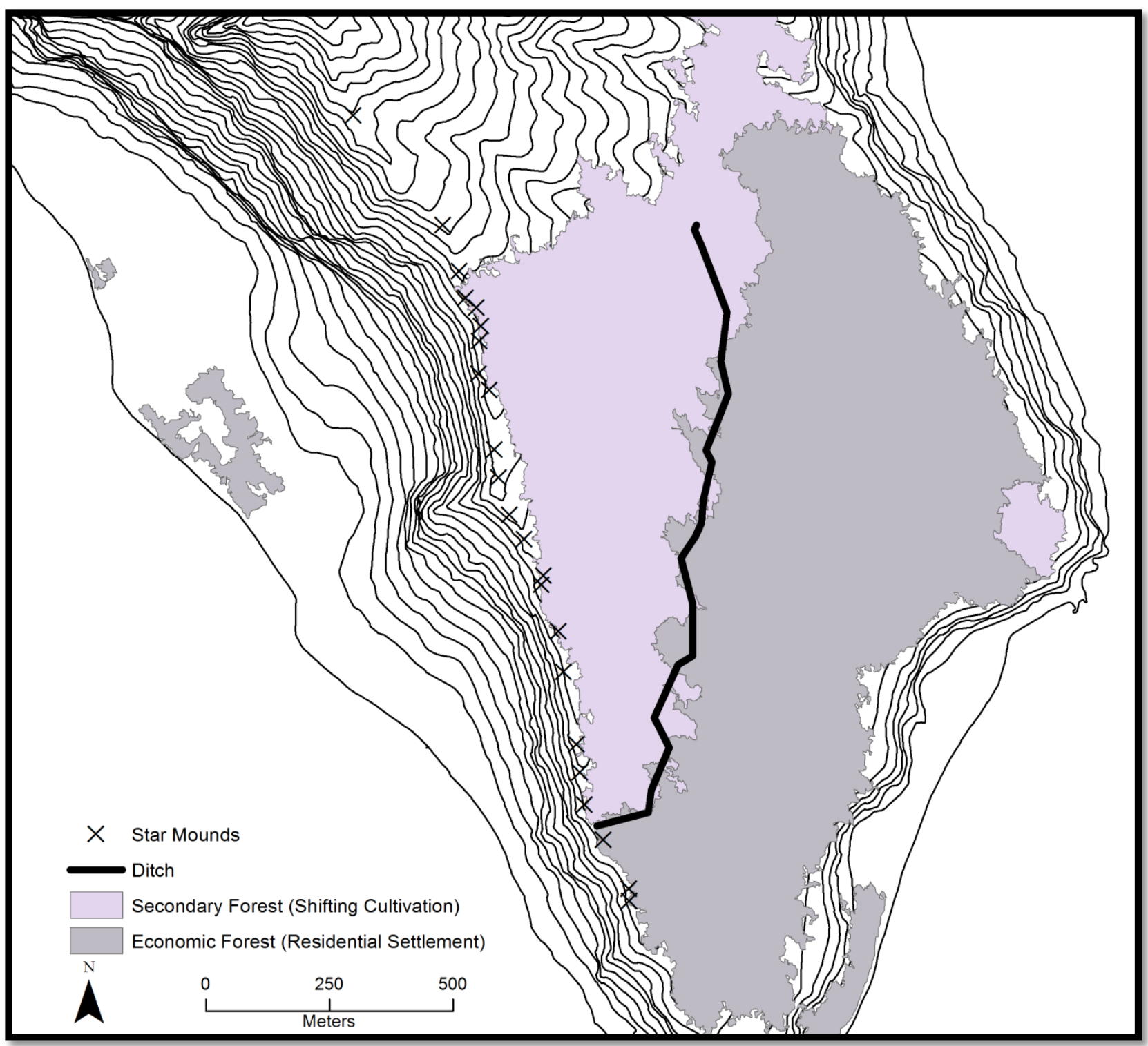

Figure 2.Spatial patterns in the Tamatupu settlement zone showing the association between the location of the ditch and vegetation zones and The density of star mounds on the inland ridgeline. (Data from Quintus 2011).

A comparable settlementzone is located on the northern third of the interior uplands of Olosega covering an area of $\approx 20$ ha and is the focus of this paper. The study area is inland of the high ridgeline that backs the modern coastal village of Sili and is known in oral history as the ancient inland village where inhabitants of modern (coastal) Sili Village used to live. The site was first reported by Kikuchi (1963:44) as Siliiuta and subsequently listed by Clark (1980) (site AS-12-1), but neither investigator visited the site. A more proper designation for the site, and one followed here, is Sili-i-uta, or Sili inland. Nearly 20 years later, a cursory investigation by 
Suafo'a and Clark identified some terraces in the uplands above coastal Sili (or Sili-i-tai), although they were able only to reach the margins of what was thought to be the old Sili-i-uta settlement (Suafo'a 1999). Still,while the existence of an inland settlement was confirmed from oral history and limited reconnaissance survey, the true nature of the terrain, the settlement features, and their distribution remained unknown.

\section{LIDAR DIGITAL SURVEY：METHODS}

\subsection{Dataset}

In the summer of 2012, aerial lidar datacollection was undertaken by the NOAA Coastal Services Center in partnership with the American Samoa Government (ASG) Department of Commerce, the U.S. National Park Service, and other ASG agencies (for details, see Raber 2012). The lidar dataset was collected using an Optech lidar system attached to a twin-engine Beechcraft King Air 90 flying at a height of 1219 m, with an overlap of 50\% and a line spacing of $395 \mathrm{~m}$. Point clouds were generated and manipulated in Optech and GeoCue software before being imported into TerraScan and TerraModeler. From these, bare earth models were generated with the resultant bare earth digital elevation model (DEM) having a horizontal resolution of 1 $\mathrm{m}$. The bare earth DEM was imported into ArcGIS 10.1 where derivative products were generated. Technical details regarding Lidar data acquisition are presented in Table 1.

The lidar dataset was made available to the authors as we entered the field in the summer of 2013. With those data in hand, we were able to engage in a preliminary round of ground truthing to test the reliability of the lidar imagery for identifying the range of features in the upland settlements of Ofu. The locations of features found during the ground survey of Tufu and A'ofa were recorded using Trimble GeoXT series GPS rover units, which have submeter accuracy. The GPS coordinates were imported into ArcGIS 10.1 for analysis.Ground-based coordinate data were then compared with a slope map derived from the lidar dataset. This comparison illustrated the association between field-observed terraces and areas of $0-10^{\circ}$ slope in Tufu (Fig. 3 ). The primary limitation was the inability to distinguish residential from non-residential terraces. Star mounds were identified on the ridgetopsand ditches were recognizable, as well.

Having established the efficacy of lidar imagery for identifying features, we expanded our lidar-based digital survey to the region of Olosega thought to be the location of old Sili-i-uta.

212 Feature-Density (HFD) zone to define the study area, and the semi-automated identification of

213 individual archaeological features within the identified HFD zone.

214 Table 1 Details of lidar data acquisition (Raber 2012)

\begin{tabular}{llllll}
\hline $\begin{array}{l}\text { Scan } \\
\text { Rate }\end{array}$ & $\begin{array}{l}\text { Field of } \\
\text { View }\end{array}$ & $\begin{array}{l}\text { Laser Pulse } \\
\text { Rate }\end{array}$ & $\begin{array}{l}\text { Maximum Point } \\
\text { Spacing }\end{array}$ & $\begin{array}{l}\text { Average Point } \\
\text { Density }\end{array}$ & $\begin{array}{l}\text { Root Mean } \\
\text { Square Error }\end{array}$ \\
\hline $37 \mathrm{~Hz}$ & $36.0^{\circ}$ & $70,000 \mathrm{hz}$ & $0.838 \mathrm{~m}$ & $1.43 \mathrm{pts} / \mathrm{m}^{2}$ & $0.074(7 \mathrm{~cm})$ \\
\hline
\end{tabular}




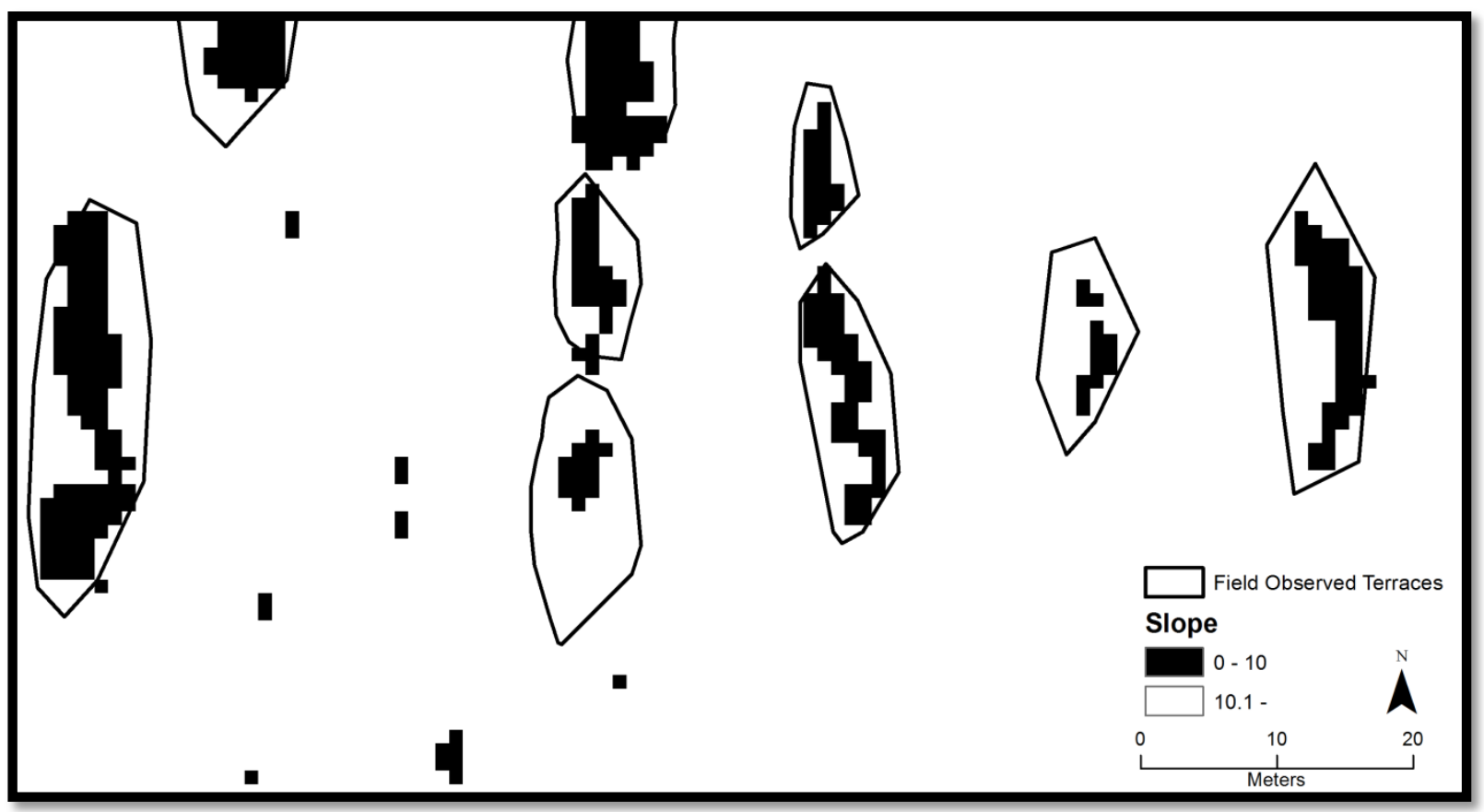

Figure 3. The association between field observed terraces and areas of $0-10^{\circ}$ slope in Tufu

\subsection{Identifying Earthen Modificationsand Defining HFD Zones}

While earthen structures are clearly visible inlidar-derived hillshade and slope maps (Fig.4),this study used a GIS procedure in which the semi-automated extraction of anthropogenic earthen modifications was accomplished using methods similar to those of McCoy et al. (2011a).Using a lidar dataset, McCoy and colleagues utilized a slope contrast procedure to identify and digitize pondfield terraces. Terraces are often built in heavily sloping land and create land surfaces that are at odds with the natural landscape. By determining the average slope of these terraces, and classifying a slope map based on the morphology of terraces, individual features can be extracted. This methodology is iterative, based on trial-and-error, and the validity of the GIS procedure is checked by visual examination of a subset of known features in other settlement zones.

Natural slope in Sili-i-uta ranges from $\approx 20-35^{\circ}$, and terraces range from $0-15^{\circ}$ in slope based on previous research on Ofu and Olosega (Quintus 2014; Quintus and Clark 2012). The identification of terraces in Sili-i-uta, therefore, was based on the assumption that confined areas of $0-15^{\circ}$ slope in otherwise contrasting land are terraces. This value is slightly higher than that employed to extract features in Tufu during a previous project because the natural slope is steeper in Sili-i-uta. Slope was displayed using two classes in ArcGIS: areas above or below $15^{\circ}$ (Fig. 5). This slope map was reclassified in ArcGIS, and the reclassified map was converted into vector format (polygon shape). Polygons generated from the slope contrast map were classified as natural slope or human-constructed features, with those polygons formed by slope of less than $15^{\circ}$ representing the latter. These polygons generally correspond to areas manually identified as 
anthropogenic features as well, but some noise was still present. To remove this noise, polygons $<20 \mathrm{~m}^{2}$ were removed from analyses, as this was the minimum size of terraces identified during 241 pedestrian survey of Ofu and Olosega.

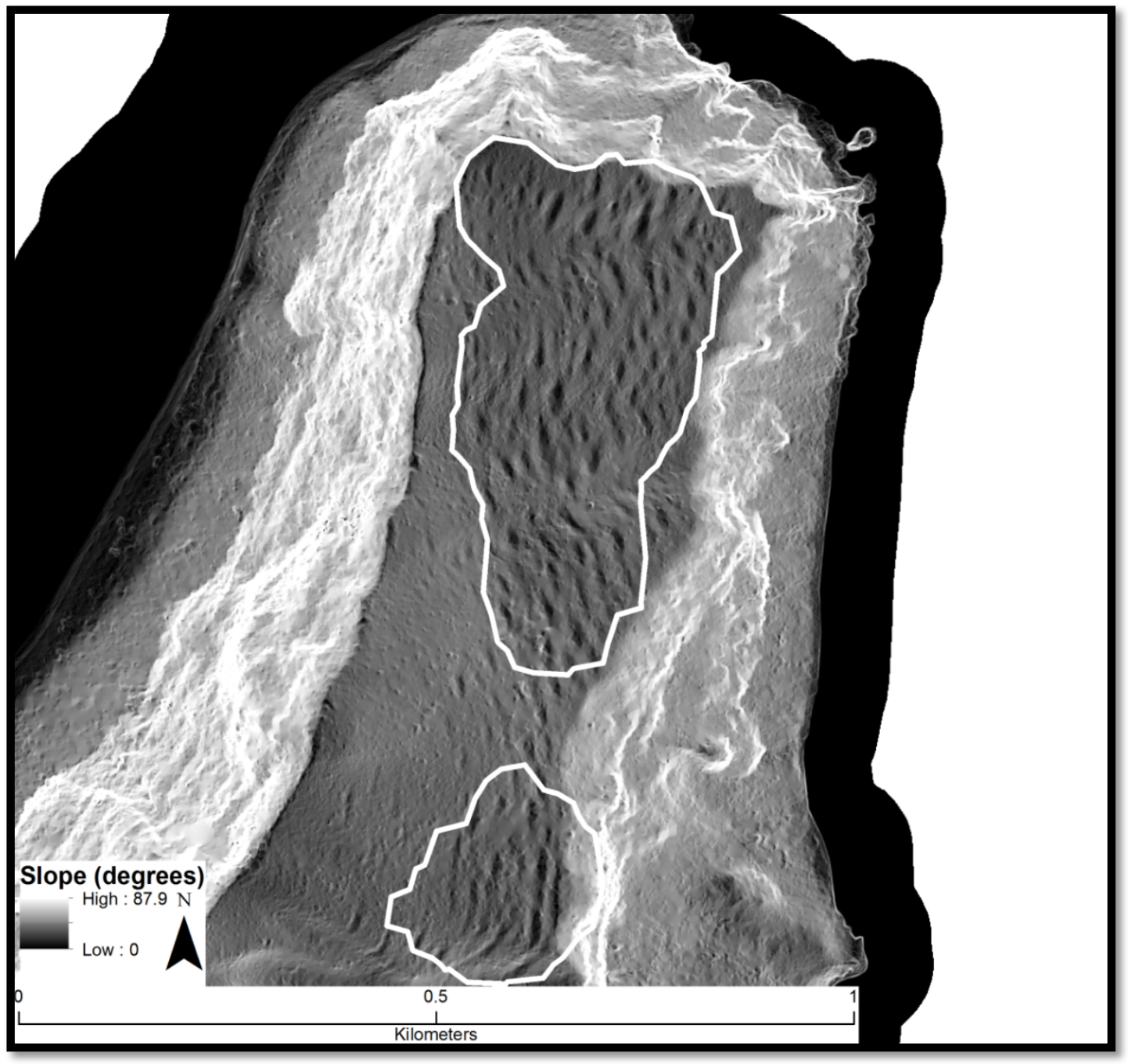

Figure 4. Lidar-derived slope map illustrated the ability to identify artificial terraces (dark polygons). White outlines represent the boundaries of high feature density zones defined by analyses in this project.

The documentation of HFD zones on the northern half of Olosega was accomplished by the examination of terrace density.HFD zones may be compared to traditional sites, but we made an attempt to quantitatively identify the boundaries in this study. The HFD zone in this study, then, can be compared to settlement zones elsewhere on Olosega and Ofu.As a way to calculate feature density, all polygons were converted to points, with a point generated for each polygon vertex. Boundaries of a HFD zone that constituted the study area were created by analyzing the point density across the landscape using a raster threshold of 0.025 (value represents the number of points when divided by neighborhood area) (Fig. 6). Cliffs formed the eastern, western, and northern extent of the unit of analysis and the southern boundary of analysis was formed by the 
southern boundary of the generated HFD zone. While two high density zones were identified during this procedure, only the larger of the two is considered here.

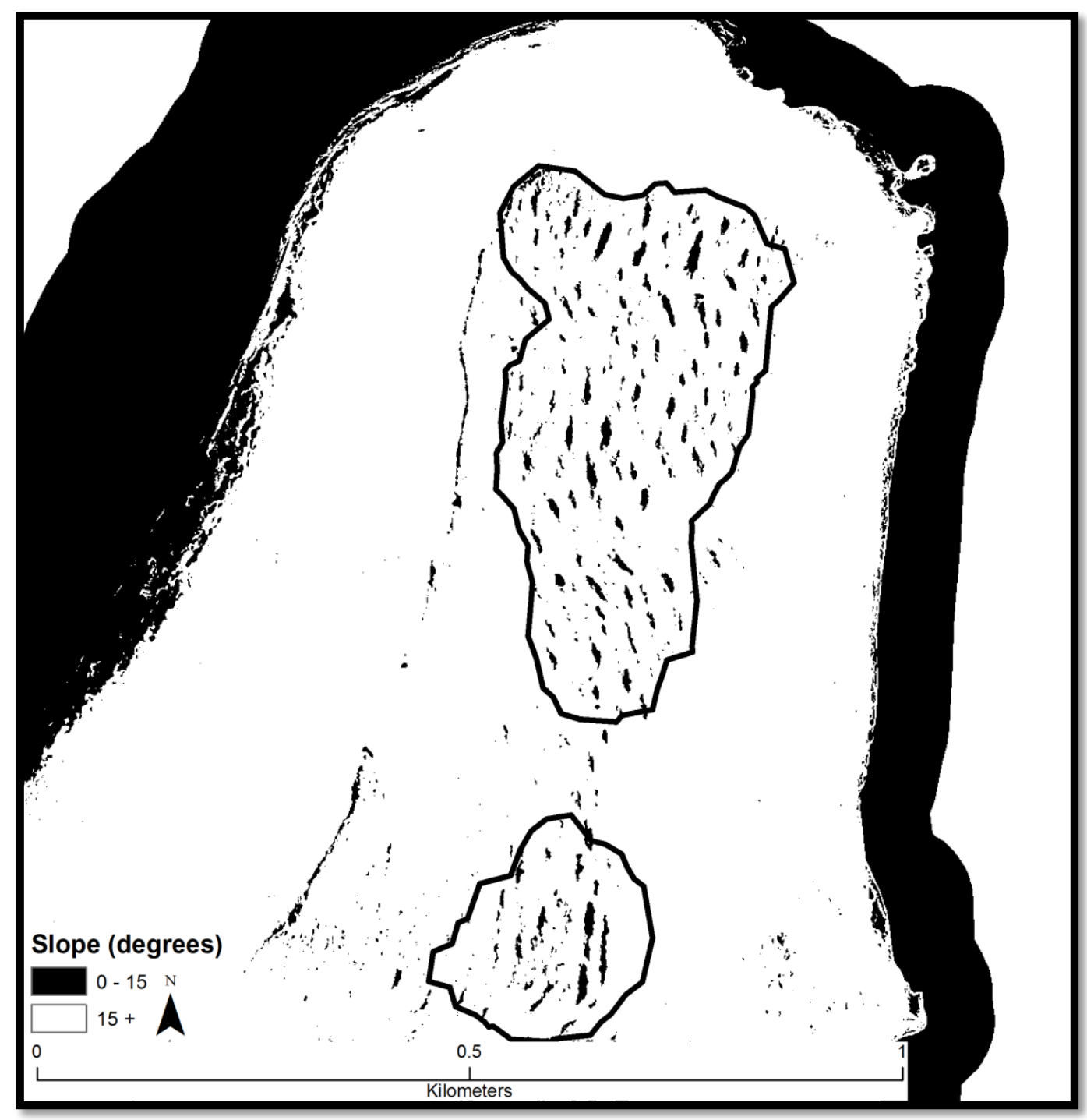

Figure 5. Classified slope map showing the distribution of terraces with defined high feature density boundaries (black outline)

Individual features were extracted using the $0-15^{\circ}$ polygon file. These polygons were manipulated to create a better representation of each feature through a visual examination of a slope map and a principal component hillshade integrating four hillshades with altitudes of $45^{\circ}$ and azimuths of the four cardinal directions.However, any manipulation was minimal. Additionally, five polygons were drawnaround areas of contrasted slope to mark possible terraces, which were not identified by the slope contrast methods employed, likely a result of more severe slope in the areas surrounding these potential features.All polygons $>20 \mathrm{~m}^{2}$ were classified as terraces, labelled with a prefix L, and numbered sequentially. Terrace area was 


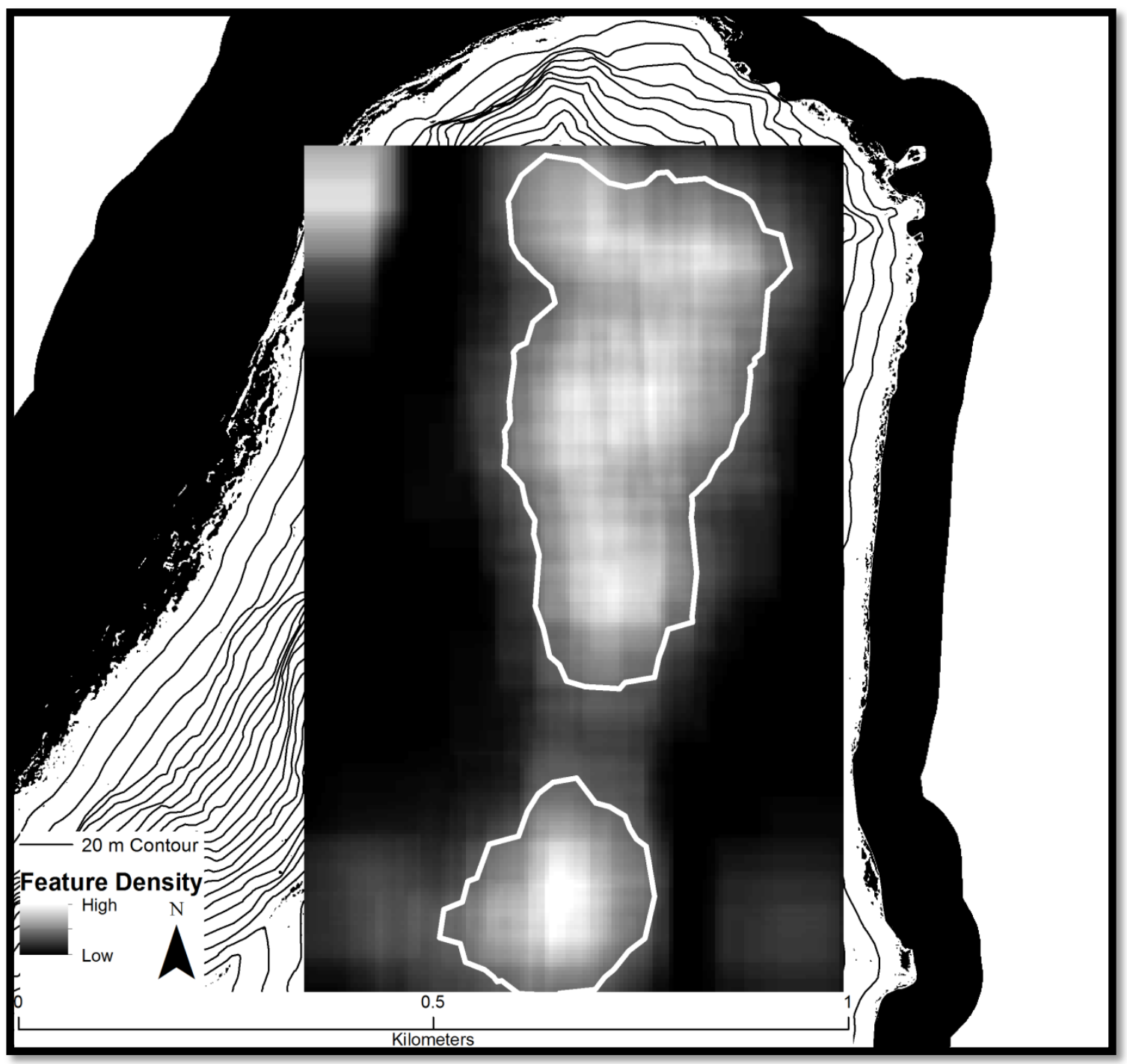

Figure 6 Results of the point density analysis with white outlines highlighting the raster threshold. Sili-i-uta is the larger of the two zones

\section{LIDAR DIGITAL SURVEY: RESULTS}

\subsection{Sili-i-uta}

Through the examination of the lidar dataset, we were able to identify and record 104 terraces in theSili-i-uta study area (Fig. 7). The surface areas of these features rangefrom 67-731 $\mathrm{m}^{2}$, with a mean of $214 \mathrm{~m}^{2}$ (s.d. $=102 \mathrm{~m}^{2}$ ). When plotted sequentially, the distribution among terrace sizes is almost continuous, with few natural breaks in the dataset. Two outliers are apparent at the right tail of the distribution: the largest features in the zone at $537 \mathrm{~m}^{2}$ (L-92) and $731 \mathrm{~m}^{2}$ (L-97). One possible ditch feature wasalso identified with a length of $\approx 350 \mathrm{~m}$, running 
from Alei Ridge to the eastern cliff edge at the southern extent of the HFD zone. The full extent of this feature is not known,although it appears similar to the large ditch featureat Tamatupu zone(southern half of the island). The ditch appears to be absent within a natural drainage but is present on either side, suggesting that it may drain into the drainage.

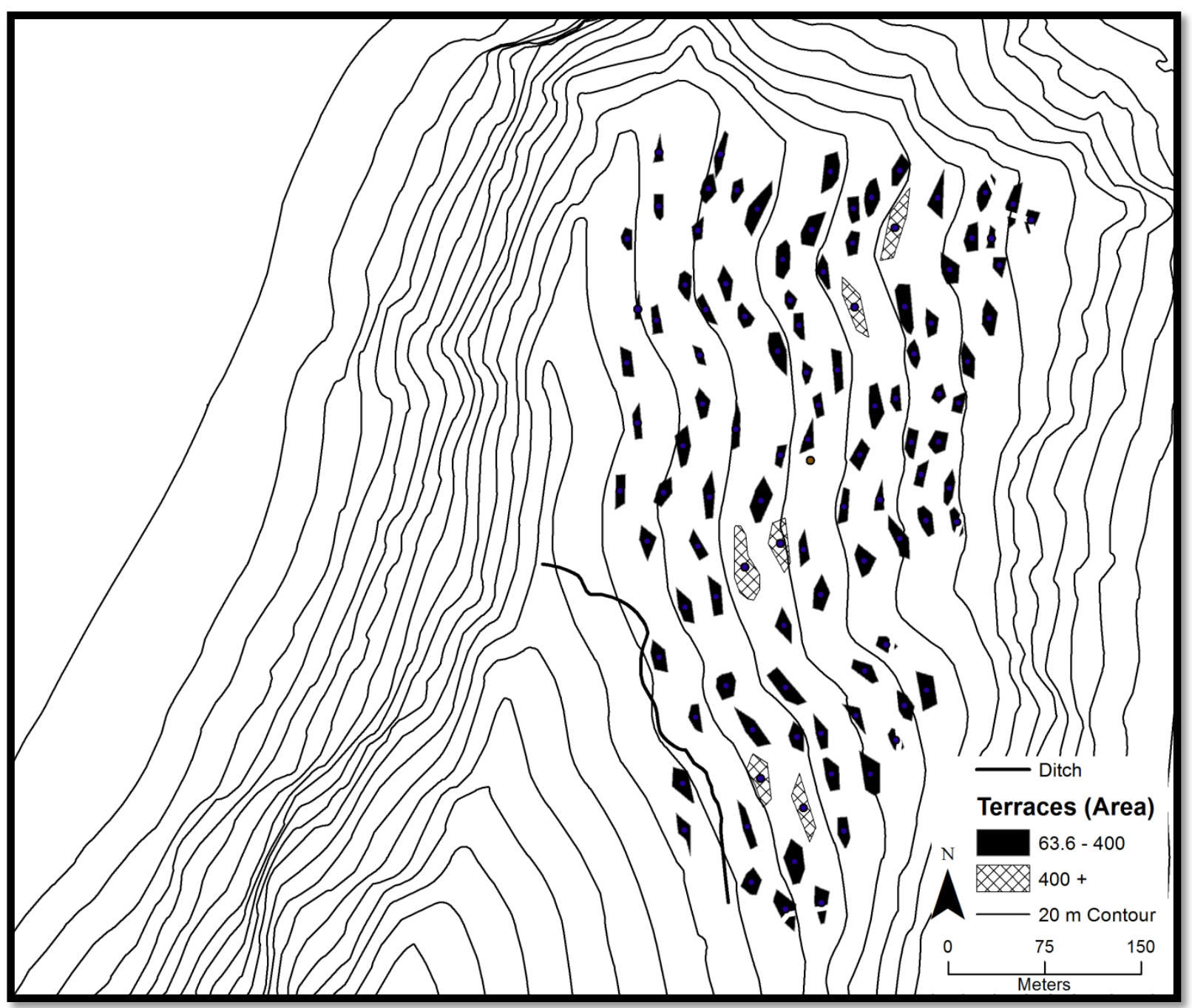

286

288

289

290

291

292

293

294

295

296

297

Figure 7. Distribution of terraces, displayed in terms of size, and a ditch feature in Sili-i-uta

When the dataset is analyzed as a whole, terraces are distributed in a dispersed pattern (nearest neighbor ratio=1.38; $\mathrm{z}$-score $=7.47$; $<<0.01)$.Terraces with a surface area $<400 \mathrm{~m}^{2}(\mathrm{n}=6)$ cluster into three groups of two, and the central grouping includes the largest terrace in the HFD zone (L-97). There is a broad correlation between the location of terracing and the distribution of modified/economic forests (e.g., Artocarpus altilis, Cocos nucifera, Inocarpus fagifer, Aleurites moluccanus), mapped previouslyfrom high resolution satellite imagery (Liu and Fisher 2007). In total, $86 \%$ of the vegetation within the HFD zone is classified as modified forest (approximately $127,000 \mathrm{~m}^{2}$ of $147,000 \mathrm{~m}^{2}$ ), and88\% (92 of 104) of the terraces are dispersed amongst this economic forest zone. Additionally, those terraces outside of the economic forestzone 
aresignificantly smaller than those inside (inside terrace mean $=221.6 \mathrm{~m}^{2}$, outside terrace mean=157.6 $\mathrm{m}^{2}$; Mann-Whitney U Test, $\mathrm{n}=104 \mathrm{U}=766.5$, $\mathrm{p}=0.029$ ), which may reflect functional differences.Such a situation, where economic trees are situated amongst large terraces, is reminiscent of modern and historic land use in which tree cropping was practiced in residential zones (Quintus 2012). The possible ditch feature at the southern extent of the settlement unit is situated at the edge of the modified forest, which is generally downslope (northeast) of the ditch (Fig. 8), a similar pattern to that identified at Tamatupu.The nature and distribution of archaeological features signals that the Sili-i-uta HFD density zone is comparable in form to settlement zones previously identified on Ofu and Olosega.

\subsection{Comparison}

To partially evaluate the accuracy and efficiency of this digital survey, and to examine the variability of individual settlement zones on Ofu and Olosega, characteristics of Sili-i-uta were compared and contrasted with the three zones surveyed using traditional pedestrian techniques: A'ofa ( $\approx 49$ ha) and Tufu ( $\approx 18 \mathrm{ha}$ ) on Ofu, and Tamatupu on Olosega ( $\approx 120 \mathrm{ha}$ ). Other archaeological remains are distributed across the landscape of each island, but these four areas have high-density clustering. Because terraces are easily identified using the lidar dataset, these are the units of comparison, although other feature types are mentioned in passing.

In each zone, terrace size is variable (likely an indicator of variable function), and clear outliers are visible at the upper end of the size distribution of each (Table 2). The smallest terrace within Sili-i-uta is larger $\left(64 \mathrm{~m}^{2}\right)$ than the smallest features in A'ofa, Tufu, and Tamatupu. The largest terrace in Sili-i-uta is larger $\left(731 \mathrm{~m}^{2}\right)$ than the largest features of A'ofa and Tufu, but not Tamatupu. The slight discrepancies between the terrace sizes of A'ofa, Tufu, and Sili-i-uta may relate to difference in how they were measured, which is suggested by similar size ranges. The smallest and largest samples from Sili-i-uta are roughly $30 \mathrm{~m}^{2}$ larger those of A'ofa and Tufu. When the area of all features in Sili-i-uta is subtracted by $30 \mathrm{~m}^{2}$, measurements are more in line with those of A'ofa and Tufu and the size of terraces in each zone is not statistically different (i.e., Mann-Whitney U Test: Sili-i-uta and A'ofa, n=154, U=2621, p=0.934; Mann-Whitney U Test: Sili-i-tua and Tufu, n=162, U=2581, p=0.127; Mann-Whitney U Test: A'ofa and Tufu, $\mathrm{n}=108, \mathrm{U}=1625, \mathrm{p}=.281$ ). Tamatupu remains an outlier; the difference of terrace size between Tamatupu and A'ofa is statistically significant, with those in Tamatupu being larger (MannWhitney U Test, $n=238, U=3473, p=0.005$ ). The largest terrace observed in Tamatupu was more than three times the size of any recorded in Tufu or A'ofa. Visual inspection of the slope map derived from the lidar dataset confirms the large size of this feature relative to others. 


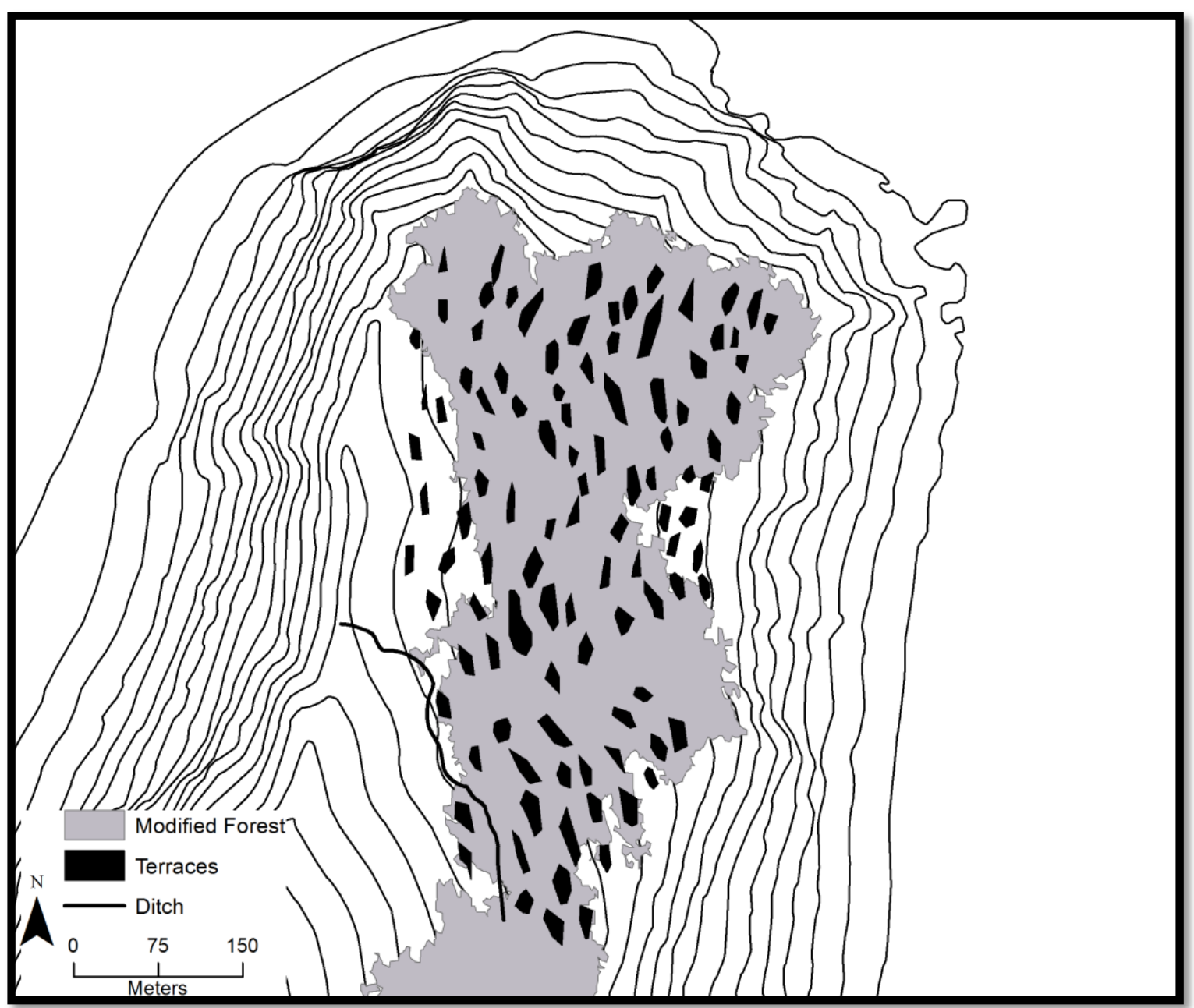

Figure 8. The associationbetween terracing and modified forest in Sili-i-uta

Table 2 Comparison of each settlement zone

\begin{tabular}{ccccccc}
\hline & $\begin{array}{c}\text { Surveyed } \\
\text { Area }\end{array}$ & $\begin{array}{c}\text { Terraces } \\
\text { Recorded }\end{array}$ & $\begin{array}{c}\text { Terrace Size } \\
\text { (Range) }\end{array}$ & $\begin{array}{c}\text { Terrace Size } \\
\text { (Mean) }\end{array}$ & $\begin{array}{c}\text { Star } \\
\text { Mounds }\end{array}$ & $\begin{array}{c}\text { Zone } \\
\text { Area }\end{array}$ \\
\hline Tamatupu & $60 \mathrm{ha}$ & 188 & $\begin{array}{c}27 \mathrm{~m}^{2}-2,035 \\
\mathrm{~m}^{2}\end{array}$ & $289 \pm 231 \mathrm{~m}^{2}$ & 23 & $\sim 120$ ha \\
$\begin{array}{c}\text { Sili-i-uta } \\
\text { (corrected) } \\
\text { Tufu }\end{array}$ & $\begin{array}{c}20 \mathrm{ha} \\
\text { (Digital) }\end{array}$ & 104 & $34 \mathrm{~m}^{2}-701 \mathrm{~m}^{2}$ & $184 \pm 103 \mathrm{~m}^{2}$ & 5 & $\sim 20$ ha \\
A'ofa & $10 \mathrm{ha}$ & 58 & $18 \mathrm{~m}^{2}-636 \mathrm{~m}^{2}$ & $174 \pm 133 \mathrm{~m}^{2}$ & $<10 ?$ & $\sim 18$ ha \\
\hline
\end{tabular}

The nature of other feature types represented are broadly consistent between all four zones (see Clark et al. 2012; Quintus 2011, 2012, 2014; Quintus and Clark 2012), suggesting the comparability of human activities in each area, though differences are also apparent. Ditches have been identified in all four zones, although they are morphologically variable. Ditches on Olosega stretch the linear length of eachsettlement zone beyond the main areas of terracing. On Ofu such long ditches are absent but, instead, shorter ditches are within the settlements and serve 
to demarcate plots of sloping land presumably used for cultivation. Ditched terraces

343 (ceremonial/religious) have been confidently identified in only Tamatupu and A'ofa. These may yet be found in Sili-i-uta during pedestrian survey, but the visibility of these features on hillshades and slope maps of A'ofa and Tamatupu suggest that the lack of digital visibility of these featuresatSili-i-utacorrectly indicates their absence. Star mounds have been identified on both islands, situated outside of the primary residential zones on surrounding ridgelines. The morphological variability of this feature type is unknown, however, and the few examplesfound on Ofu were not recorded in the same detailas those on Olosega.

\section{DISCUSSION}

The above comparisons among a lidar-derived survey dataset and three field recorded datasets demonstrate the applicability of digital surveys of earthen modifications for the examination of community and regional-level landscape studies in the tropical Pacific. Nevertheless, digital surveys are constrained in some ways. Previous field surveys have demonstrated the importance of remains on the surface of features (e.g., coral/basalt paving, curbing alignments, surface ovens, and artefacts) in understanding the intra-zone patterning of different activities. Feature type and size, as reported here, are certainly important factors in understanding spatial patterns within each zone (Davidson 1969; Holmer 1980; Quintus 2011; Quintus and Clark 2012), but they are just two sources of variability. Still, we consider these different lines of evidence as convergent, highlighting important aspects of intra-site variation that are complementary. Interpretations reached studying surface remains are parallel to those presented here for the lidar dataset.

The distribution of anthropogenic features on islands of the Samoan Archipelago, particularly those islands of the Independent Nation of Samoa, has been described as dispersed, exhibiting little evidence of nucleation until the historic period (Davidson 1969, 1974a,b,c; Green 2002; Holmer 1976, 1980; Jackmond and Holmer 1980; Jennings et al. 1982). Even across the landscapes of the larger islands of 'Upolu and Savai'i, though, clusters of households have been identified and defined as wards, which may mark individual social and settlement units (Holmer 1980).In one area of Savai'i, Wallin and Martinsson-Wallin (2007) argue that individual settlement zones may have functioned differently, with those to the inland suggested to be associated with ritual activities and those on the coast with common residential activity. These same researchers argue that a trend of increased clustering of settlement structures is apparent through the cultural sequence (Wallin and Martinsson-Wallin 2007:85). On Tutuila, clusters of surface features that may represent communities are rare, although they do exist on broad slopes in the interior uplands (Clark and Herdrich 1988, 1993; Pearl 2004). The boundaries of these settlements are more easily defined, as the topographic conditions of the islands, unlike 'Upolu and Savai'i, restrict the area within which habitation was possible. Even though the identification of discrete settlement zones has been accomplished, few studies have examined relationships among zones at a regional scale. 
The detailed documentation of four settlement zones on two closely aligned islands, three by combined pedestrian and digital survey and one by digital surveyalone, allows for a preliminary examination of regional settlement patterns. From the above comparison of terraces in the four zones, many of which are residential features, it can be inferred that one zone, Tamatupu, is different from the others. Although there is no doubt of variability between A'ofa, Tufu, and Sili-i-uta, there are general consistenciesamong them in terrace size relative to Tamatupu. These differences may relate to the nature of socio-political relations on Ofu and Olosega. Settlement pattern analyses have been used to examine questions of competition, cooperation, and aggregation that relate to issues of social hierarchy at multiple spatial scales (e.g., Brandt 1994; Fletcher 2008; Johnson 1980; Morrison 2012; Peebles and Kus 1977; Smith 1978; Wright and Johnson 1975). At the regional level, these analyses require the comparison of discrete settlement zones and the evaluation of variation in size and structure. The nature of relationships among zones is dependent on a number of factors, specifically the demonstration that all were used contemporaneously and the differential identification of material remains indicative of status and rank.

Chronological data are only available from two settlement zones, both on the island of Ofu (Quintus 2014). Earthen structures in both zones, A'ofa and Tufu, began to be built around the same time, at the beginning of the $2^{\text {nd }}$ millennium AD. Additionally,similarities of spatial patterning and feature types in all four zones hint at the relative contemporaneity ofthe four settlement zones. Even if contemporaneity can be assumed, however, the patterns of interest late prehistoric or early historic period.

The distribution of star mounds associated with each settlement unit may mark differences in the amount of control or influence exerted by chiefs or leaders of each. These features are substantial and require group effort for construction, but their importance in political contexts stems from their presumed function as arenas for the chiefly sport of pigeon catching. In this way, the distribution of these features may be a measure of status and rank. The distribution of star mounds on both islands is not well understood, but data suggest that these features are foundin a far higher density on Mata'ala Ridge overlooking, and presumably associated with, Tamatupu than elsewhere on Olosega and Ofu.Pedestrian survey of the ridgeline revealed 23 star mounds - also found in the digital inspection - yielding a density of 10 features $/ \mathrm{km}$ on the ridgeline (highest density in Samoa). While star moundshave been identified on the ridge overlooking Sili-i-uta ( $\mathrm{n}=5$; Suafo'a 1999), the density of these features is much lower ( $\approx 3$ features $/ \mathrm{km}$ of ridgeline). The distribution and frequency of star mounds on Ofu remains poorly documented, but limited survey of some ridgelines together with digital inspection has identified only five star mounds. Additional star mounds probably will be identified eventually on the ridgelines above Sili-i-uta, A'ofa, and Tufu, but, based on the digital survey, we are confident that the density will be nowhere near that of Mata'ala Ridge. 
It has been demonstrated that terraces in Tamatupu, the majority of which likely reflecting residential activities, are larger than those in the other high feature density zones (settlement units or villages) (Fig. 9; Table 2). If the size of individual terraces can be used as a measure of household or family influence, the largest feature in Tamatupu is consistent with a group that has more influence than others in Tamatupu or any settlement zone on Ofu or Olosega. The largest of these features, situated near the center of the settlement unit, may correspond to a feature ethnographically identified as the house site of the Tui Olosega (Mead 1969:210), the political paramount of the island. This is also consistent with ethnohistoric records, wherein Wilkes (1852:155) stated that the "king or chief of these islands [Manu'a] resides at Oloosinga [sic].”

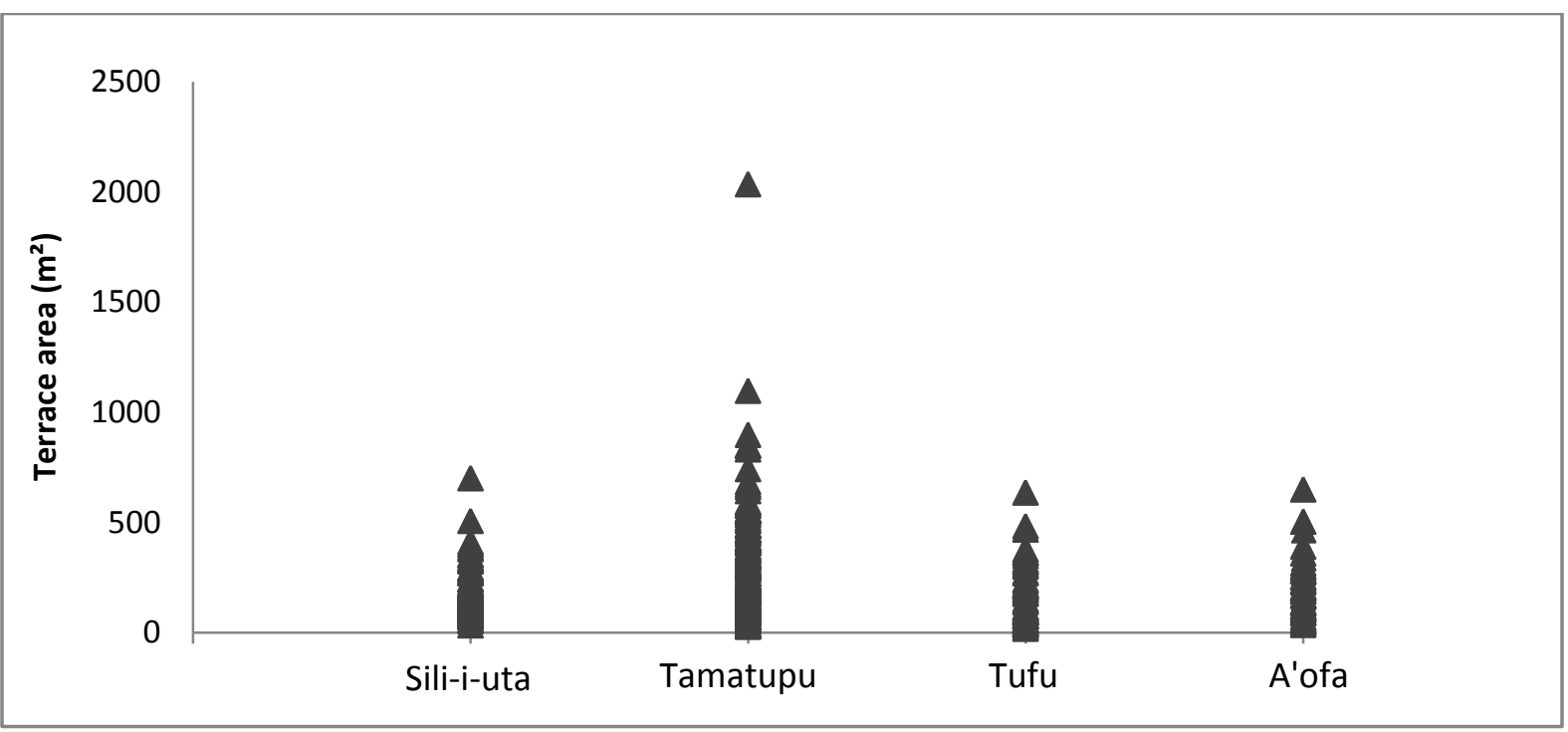

Figure 9. The size distribution of terraces in each high feature density zone. Each symbol represents an individual terrace.

These data arefurther consistent with a two-tiered settlement hierarchy. Variability exists betweenA'ofa, Tufu, and Sili-i-uta, but these are largely similar whenanalyzed at the settlement zone scale. Tamatupu represents a clear outlier, distinguished by the number of labor intensive features that served important socio-political functions (star mounds), the larger number of religious/ceremonial structures (ditched terraces) than in any other zone, and the size of terracing, suggested to correspond with the social influence of the inhabitants. This conclusion is supported by limited ethnohistoric documentation that a politically important figure or group with influence that stretched at least across Ofu and Olosega inhabited Olosega at historic contact. The temporal depth of this specific socio-political situation is unknown, and might only have developed at the end of the prehistoric or the beginning of the historic period.

\section{CONCLUSIONS}


Thisstudyhas demonstrated the applicability of lidar datasets for regional examinations of archaeological landscapes, especially when paired with results of pedestrian survey for comparative purposes. The utilization of a lidar dataset allows for the efficient documentation of anthropogenic features across steep landscapes where terracing contrasts with the surrounding landscape (McCoy et al. 2011a). From these surveys, quantitative analyses can be undertaken to examine areasthat may be consistent with individual settlement zones. After the analysis of the individual featuresthat constitute these proposed settlement zones, the comparison among zones allows for the regional examination of settlement patterns. In the Samoan Archipelago, the examination of relationships among settlement zones has largely been lacking.

On Ofu and Olosega, four settlement zones have now been examined, with one clear outlier, creating the appearance of a hierarchical settlement system. In classic conceptions, a twotiered settlement pattern is an attribute of chiefdoms (Earle 1987:289), wherein the largest unit exerts a degree of control over the smaller ones. Such a situation is to be expected in the Samoan Archipelago where chiefdoms have been well-documented (see Goldman 1970; Meleiseā 1995; Sahlins 1958). Since this analysis of Sili-i-uta was limited to the examination of a small set of feature types, with an emphasis on one (residential terraces), inferences about inter-community relationships are preliminary. Nevertheless, these differences, when supplemented with additional evidence from archaeological investigations and ethnohistoric documents, may indicate that this regional settlement system was hierarchical, with the Tamatupu zone exerting influence over some surrounding settlements.

\section{ACKNOWLEDGEMENTS}

464 We wish to express our gratitude to the people of Ofu and Olosega who allowed us to work on 465 their islands, especially High Chief Misa’alefua Hudson, Manu’a Rep. Toeaina Faufano Autele, 466 and the Malae family. We wish to acknowledge the student and community crew members that 467 have participated in the archaeological field schools that we have conducted on the island. NPS 468 ranger Carlo Caruso and American Samoa Historic Preservation Officer David Herdrich 469 contributed logistical support and advice. This research benefited from discussions with Thegn 470 Ladefoged and Melinda Allen of the University of Auckland. The field work that contributedto 471 this study was part of a long-term settlement system investigation of American Samoa supported 472 by North Dakota State University, with associated support through agrant from the National 473 Science Foundation (BCS - 1260909). Additional funding was also provided by the University 474 of Auckland Doctoral Research Fund. We thank two anonymous reviewers for their helpful 475 comments, which improved the quality of this paper.

\section{REFERENCES} and Leonard, R.D. (eds.), The Prehistoric Southwestern Community: Models and Methods for the Study of Prehistoric Social Organization. University of New Mexico 
48ark, J.T. 1980. Historic Preservation in American Samoa: Program Evaluation and

482 Archaeological Site Inventory. Report submitted to the American Samoa Historic

483 Preservation Office, Pago Pago, American Samoa

48ark, J.T., Herdrich, D.J., 1988. The Eastern Tutuila archaeological project: 1986 final report.

485 Report submitted to the American Samoa Historic Preservation Office, Pago Pago,

486 American Samoa

48ark, J.T., Herdrich, D.J., 1993. Prehistoric settlement system in Eastern Tutuila, American

488 Samoa. Journal of the Polynesian Society 102, 147-185

489rk, J.T., Quintus, S.J., Bonk, D., 2012. A reconnaissance survey of inland Ofu Island, Manu’a

490 Group, American Samoa. Report submitted to the American Samoa Historic Preservation

491 Office, Pago Pago, American Samoa

492idson, J.M., 1969. Settlement patterns in Samoa before 1840. Journal of the Polynesian

493 Society 78, 44-88

Mgatidson, J.M., 1974a. Samoan structural remains and settlement patterns. In: Green, R.C.,

495 Davidson, J.M. (Eds.), Archaeology in Western Samoa, Vol. II. Auckland Institute and

496 Museum Bulletin 7, Auckland,pp. 225-244

Maxidson, J.M., 1974b. Specialized sites in the upper Falefa Valley. In: Green, R.C., Davidson,

498 J.M. (Eds.), Archaeology in Western Samoa, Vol. II. Auckland Institute and Museum

499 Bulletin 7, Auckland, pp. 205-209.

BoQvidson, J.M., 1974c. Upper Falefa Valley project: summaries and conclusions. In: Green,

501 R.C., Davidson, J.M. (Eds.), Archaeology in Western Samoa, Vol. II. Auckland Institute

502 and Museum Bulletin 7, Auckland, pp. 155-162

Elaßle, T.K., 1987. Chiefdoms in archaeological and ethnohistorical perspective. Annual Review

504 of Anthropology 16, 279-308

50EAd, J.S., 2003. The evolution of competition and cooperation in Fijian prehistory:

506 archaeological research in the Sigatoka Valley, Fiji. Unpublished Ph.D. dissertation,

507 Department of Anthropology, University of Hawaii

508d, J.S., 2005. Land tenure, competition and ecology in Fijian prehistory. Antiquity 79, 586-

509600

Ei€ld, J.S., Kirch, P.V., Kawelu, K., Ladefoged, T.N., 2010. Households and hierarchy: domestic

511 models of production in leeward Kohala, Hawai'i Island. Journal of Island and Coastal

512 Archaeology 5, 52-85

Eletcher, R., 2008. Some spatial analyses of Chalcolithic settlement in Southern Israel. Journal of

514 Archaeological Science 35, 2048-2058

5ilb3dman, I., 1970. Ancient Polynesian Society. University of Chicago Press, Chicago

Gir6en, R.C., 2002. A retrospective view of settlement pattern studies in Samoa. In: Ladefoged,

517 T.N., Graves, M.W. (Eds.), Pacific Landscapes: Archaeological Approaches. Easter

518 Island Foundation, Los Osos,pp. 125-152

5itlen, R.C., Davidson, J.M., 1969. Archaeology in Western Samoa, Vol. I. Auckland Institute

520 and Museum Bulletin 6, Auckland

G7teen, R.C., Davidson, J.M., 1974. Archaeology in Western Samoa, Vol. II. Auckland Institute

522 and Museum Bulletin 7, Auckland

ERezdrich, D.J., 1991. Towards an understanding of Samoan star mounds. Journal of the

524 Polynesian Society 100, 381-435

ERerdrich, D.J., Clark, J.T.. 1993. Samoan Tia 'Ave and social structure: methodological and

526 theoretical considerations. In: Graves, M.W., Green, R.C. (Eds.),The Evolution and 
Organization of Prehistoric Society in Polynesia.New Zealand Archaeological Association Monograph Series, Auckland, pp 52-63

Holmer, R.N., 1976. Mt. Olo settlement pattern interpretation. In:Jennings, J.D., Holmer, R.N., Janetski, J., Smith, H.L. (Eds.),Excavations on 'Upolu, Western Samoa. Pacific Anthropological Records No. 25, Honolulu, pp. 41-56

Holmer, R.N., 1980. Mt. Olo settlement pattern interpretation. In:Jennings, J.D., Holmer, R.N. (Eds.),Archaeological Excavations in Western Samoa. Pacific Anthropological Records No. 32, Honolulu, pp. 93-103

Hunt, T.L., Kirch, P.V., 1988. An archaeological survey of the Manu'a Islands, American Samoa. Journal of the Polynesian Society 97, 153-183

Ishizuki, K., 1974. Excavation of site SU-Fo-1 at Folasa-a-Lalo. In: Green, R.C., Davidson, J.M. (Eds.).Archaeology in Western Samoa, Vol. II. Auckland Institute and Museum Bulletin 6, Auckland, pp. 36-57

Jackmond G., Holmer R.N.,1980. Sapapali'i settlement: In:Jennings, J.D., Holmer, R.N. (Eds),ArchaeologicalInvestigations in Western Samoa. Pacific AnthropologicalRecords No. 32, Honolulu, pp. 147-152

Jennings, J.D., Holmer, R.N., 1980. Archaeological Excavations in Western Samoa. Pacific Anthropological Records No. 32, Honolulu

Jennings, J.D., Holmer, R.N., Jackmond, G., 1982. Samoan village patterns: four examples. Journal of the Polynesian Society 91, 81-102

Jennings, J.D., Holmer, R.N., Janetski, J., Smith, H.L., 1976. Excavations on 'Upolu, Western Samoa. Pacific Anthropological Records No. 25, Honolulu

Johnson, G.A., 1980. Rank-size convexity and system integration: a view from archaeology. Economic Geography 56, 234-247

Kikuchi, W.K., 1963. Archaeological Surface Ruins in American Samoa. Unpublished MA thesis, Department of Anthropology, University of Hawaii

Krämer, A., 1902-3. Die Samoa-Inseln. 2 Vol. E. Nagele, Stuttgart (1978 translation by T.E. Verhaaren, Palo Alto)

Kurashima, N., Kirch, P.V., 2011. Geospatial modeling of pre-contact Hawaiian production systems on Moloka'i Island, Hawaiian Islands. Journal of Archaeological Science 38, 3662-3674

Ladefoged, T.N., Flaws, A., Stevenson, C.M. 2013. The distribution of rock gardens on Rapa Nui (Easter Island) as determined from satellite imagery. Journal of Archaeological Science 40, 1203-1212

Ladefoged, T. N., P.V. Kirch, S.M. Gon, O.A. Chadwick, A.S. Hartshorn \& P.M. Vitousek, 2009. Opportunities and constraints for intensive agriculture in the Hawaiian archipelago prior to European contact. Journal of Archaeological Science 36, 2374-2383

Ladefoged, T. N., McCoy, M.D., Asner, G.P., Kirch, P.V., Puleston, C.O., Chadwick O.A., Vitousek, P.M., 2011. Agricultural potential and actualized development in Hawai'i: an airborne LIDAR survey of the leeward Kohala field system (Hawai'i Island). Journal of Archaeological Science 38, 3605-3619

Liu, Z., Fischer, L., 2007. American Samoa Vegetation Mapping using High Spatial Resolution Imagery. Draft report submitted to the United States Forest Service

McCoy, M.D., Asner, G.P., Graves, M.W., 2011a. Airborne lidar survey of irrigated agricultural landscapes: an application of the slope contrast method. Journal of Archaeological Science 38, 2141-2154 
\$TOCoy, M.D., Ladefoged, T.N., Graves, M.W., Stephens, J.W., 2011b. Strategies for 574 constructing religious authority in ancient Hawai’i. Antiquity 85, 927-941

\$TEad, M., 1969. Social Organization of Manua. B.P. Bishop Museum Bulletin No. 76, Honolulu \$TGleiseā, M., 1995. "To whom the men crowded": chieftainship and hierarchy in ancient Samoa. 577 In: Huntsman, J., (Ed.), Tonga and Samoa: Images of Gender and Polity. Macmillian

578 Brown Centre for Pacific Studies, Christchurch, pp. 19-36

\$YOrrison, A.E., 2012. An archaeological analysis of Rapa Nui settlement structure: a multi-

580 scalar approach. Unpublished PhD dissertation, Department of Anthropology. University

581 of Hawai'i

6q12tz, R.S., Cowley D.C., 2013. Interpreting Archaeological Topography. Airborne Laser

583 Scanning, 3D Data and Ground Observation. Oxbow Books, Oxford

B8arl, F.B., 2004. The chronology of mountain settlement on Tutuila, American Samoa. Journal

585 of the Polynesian Society 113, 331-348

B̊6bles, C.S., Kus, S.M., 1977. Some archaeological correlates of ranked societies. American

587 Antiquity 42, 421-448

688ntus, S.J., 2011. Land use and the human-environment interaction on Olosega Island,

589 Manu’a, American Samoa. Unpublished M.S. Thesis, Department of Sociology and

590 Anthropology, North Dakota State University

ธQiintus, S.J., 2012. Terrestrial food production and land use in prehistoric Samoa: an example

592 from Olosega Island, Manu’a, American Samoa. Archaeology in Oceania 47, 133-140

693ntus, S., 2014. Unpacking the process of agricultural change in prehistoric Samoa: a study of

594 Ofu Island. Unpublished Ph.D. Thesis, Department of Anthropology, University of

595 Auckland

6h6ntus, S.J., Clark, J.T., 2012. Between Chaos and Control: Spatial Perception of Domestic,

597 Political, and Ritual Organization in Prehistoric Samoa. Journal of the Polynesian Society

598 121, 275-302

Bg@er, S., 2012. Post-flight aerial acquisition and calibration report. Unpublished report

600 completed by Photo Science, Inc. Colorado Springs, Colorado

6alllins, M., 1958. Social Stratification in Polynesia. American Ethnological Society, Seattle

602ith, B.D., 1978. Mississippian Settlement Pattern. Academic Press, New York

60åfo'a, E., 1999. Reconnaissance survey of Olosega and Sili village lands: natural and cultural

604 resources. Unpublished report of the National ParkService of American Samoa, Pago

605 Pago.

606llin, P., Martinsson-Wallin, H., 2007. Settlement patterns-social and ritual space in prehistoric

607 Samoa. Archaeology in Oceania 42 Supplement, 83-89

608kes, C. 1852. Narrative of the United States Exploring Expedition during the years 1838,

609 1839, 1840, 1841, 1842. Ingram, Cooke, and Co., 227, Strand, London

Evflght, H.T., Johnson, G.A., 1975. Population, exchange, and early state formation in

611 Southwestern Iran. American Anthropologist 77, 267-289 